\title{
Design a New Multiport DC-DC Converter to Charge an Electric Car
}

\author{
Amin Abedini Rizi ${ }^{\mathrm{a}, 1, *}$, Ali Rezaei ${ }^{\mathrm{b}, 2}$ Mohammadreza Ghorbani Rizi ${ }^{\mathrm{c}, 3, *}$, Mohammadmahdi \\ Aliakbari Rizi ${ }^{\mathrm{d}, 4}$ \\ ${ }^{a}$ Department of Electrical and Computer Engineering, Mulla Sadra Technical University, Ramsar, Iran \\ ${ }^{\mathrm{b}}$ Department of Electrical and Computer Engineering, Quchan University of Technology, Quchan, Iran \\ ${ }^{\mathrm{c}}$ Department of Electrical and Computer Engineering, Beheshti Ardakan University, Ardakan, Iran \\ ${ }^{\mathrm{d}}$ Department of Electrical and Computer Engineering, Shahrekurd University, Shahrekurd, Iran \\ ${ }^{1}$ Aminabedini.esfahan@ gmail.com; ${ }^{2}$ Rezaei.ila@gmail.com; ${ }^{3}$ Mohammadrezaghorbani.m74@ gmail.com; ${ }^{4}$ \\ mohammadaliakbari@gmail.com \\ * corresponding author
}

\section{ARTICLE INFO}

\section{Article history}

Received January 07, 2022

Revised January 25, 2022

Accepted February 06, 2022

\section{Keywords}

Photovoltaic System;

Fuel cell System;

DC-DC Converter;

Electric Car's Battery System

\section{ABSTRACT}

Due to the lack of oil and gas, electric cars have been in high demand in recent years. There are three kinds of electric vehicles, including Hybrid Electric Vehicles (HEV), Battery Electric Vehicle (BEV), and Plug-in Hybrid Electric Vehicle (PHEV). There is no charging portion for the batteries in the HEV where the batteries are not connected to the power grid, but BEV and PHEV can be charged by a power outlet, and the number of batteries is increased. In order to charge the battery of the Electric Vehicles (EVs), there are two ways, including the power grid and renewable energies. There are already quite a few outages in many countries, and using a power grid for charging the batteries is not suitable. Therefore, the only choice is renewable energy sources such as photovoltaic (PV), fuel-cell (FC), and so on. Furthermore, to use the DC voltage of the renewable sources, two conventional DC-DC converters are required to deliver the energy of the sources to the bank of batteries. To feed the batteries, this paper proposes a two-input one output topology that contains PV, FC, and other components. Simulation results demonstrate that the presented system is improving the system because it is able to feed the batteries with low power losses and low ripples.

This is an open-access article under the CC-BY-SA license.

\section{Introduction}

Air pollution is a very important problem in big cities. Needless to state that the huge amount of air pollution nowadays belongs to vehicles [1][2][3]. As the population of the world increases rapidly, the number of cars also increases. In addition, the number of outages in all the countries is increasing yearly owing to the lack of oil and gas [4]. It is obvious that electric cars can decrease air pollution [5]. Each electric car contains dc to dc converters, batteries, wiring, and sources of energy [6][7]. To prevent air pollution and lower the negative points of using electric cars, solar systems and fuel cell systems are the two suitable sources of energy [8][9]. Solar energy is accessible, clean, and abundant in all corners of the world. On the other hand, the generated power of the solar system and fuel cell is DC which can be used for quite a few medical equipments [10][11][12]. Therefore, there is a special need for power converters. To transfer the energy of the renewable resources to the batteries, two dc- 
dc converters are required [13][14]. In this paper, a multiport dc to dc topology is utilized to feed the batteries. It is possible to use converters with high-frequency transformers, which is called an isolated converter. However, the size and the cost of such a converter are too high [15]. Therefore, most electric cars use non-isolated dc to dc converters [16][17][18]. In order to extract the highest amount of solar energy, maximum power point tracking (MPPT) is used to get the maximum power [19][20]. There are quite a few MPPT approaches. In this paper, the basic method is optimized with an artificial intelligence system to have a faster and more accurate tracking system [21][22]. The proposed topology of the new system is shown in Fig. 1.

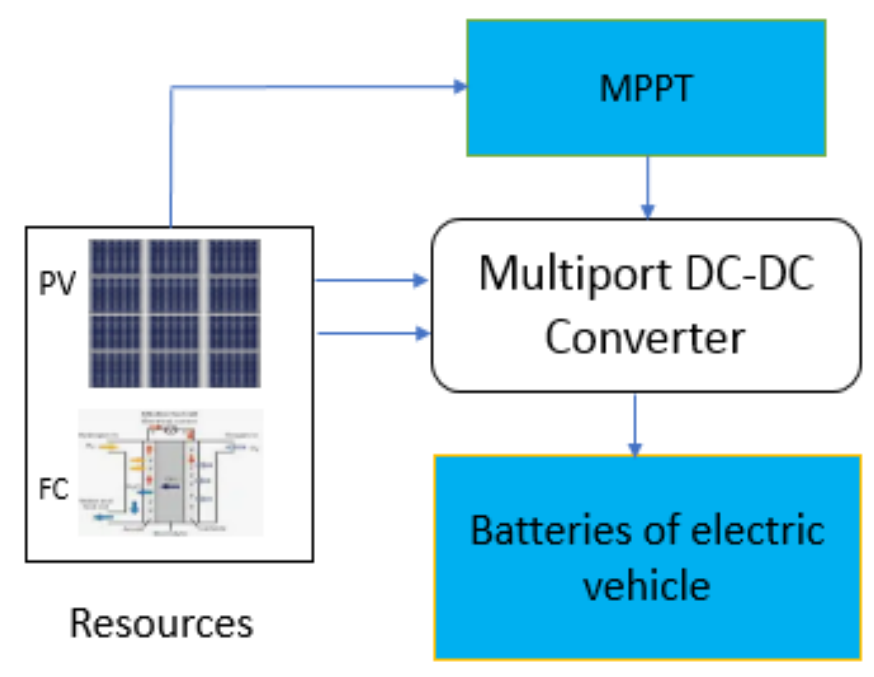

Fig. 1. Proposed topology

According to Fig. 1, the presented topology has several parts, including the resources of energy, a bank of batteries, an MPPT controller, and the proposed DC-DC converter. The main goal of the research is to lower the power losses when using power converters. The paper structure is Introduction, Renewable energy sources, Proposed DC-DC topology, Result, and Conclusions.

\section{Renewable Energy Sources}

The sources of energy for the proposed system are PV and FC. PV uses the energy from the sun radiation to convert it to electric energy, and FC uses hydrogen.

\subsection{Photovoltaic System (PV)}

The photovoltaic system contains some parallel and series of solar modules. Each solar module, on the other hand, contains some cells which are connected in series and parallel again to feed the bank of the batteries [23][24]. Fig. 2 depicts the model of a PV cell.
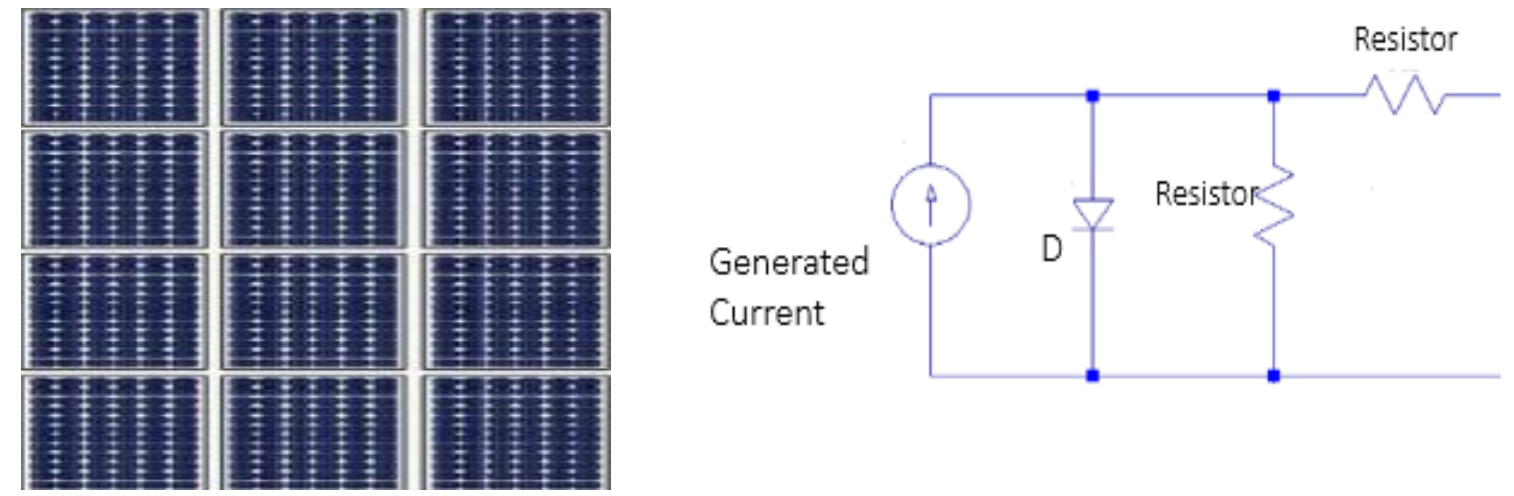

Fig. 2. The model of a PV cell 
The generated current of each module is demonstrated in Eq. (1).

$$
I=N_{P} I_{S H}-N_{P} I_{S}\left[\left(\frac{q\left(\frac{V}{N_{S}}+\frac{I R_{S}}{N_{P}}\right)}{K T A}\right)-1\right]-\frac{\left(\frac{N_{P} V}{N_{S}}+I R_{S}\right)}{R_{S H}}
$$

Based on Eq. (1), the output current and voltage are I and V, respectively. The number of cells in parallel is $\mathrm{Np}$, and the number of cells in series is Ns. $\mathrm{K}$ is the Boltzmann factor, and $\mathrm{T}$ is the temperature of the solar cells [25]. For extracting the maximum amount of energy, an MPPT method is required. In this paper, a combination of basic methods and intelligent methods is used, which can be operated with buck, boost, and other topologies of the converters [26]. Even the proposed MPPT can be used with some new topologies of converters, including double boost, quadratic boost, and double cascaded boost converters [27]. In this paper, a new topology is utilized, which performs like a buck converter. The proposed approach uses three switches that increase the electromagnetic noises but lower the cost and the size of the system dramatically. The amount of solar energy depends on solar radiation and cell temperature [28][29]. Fig. 3 shows the radiation of the sun and the temperature of the solar panel.
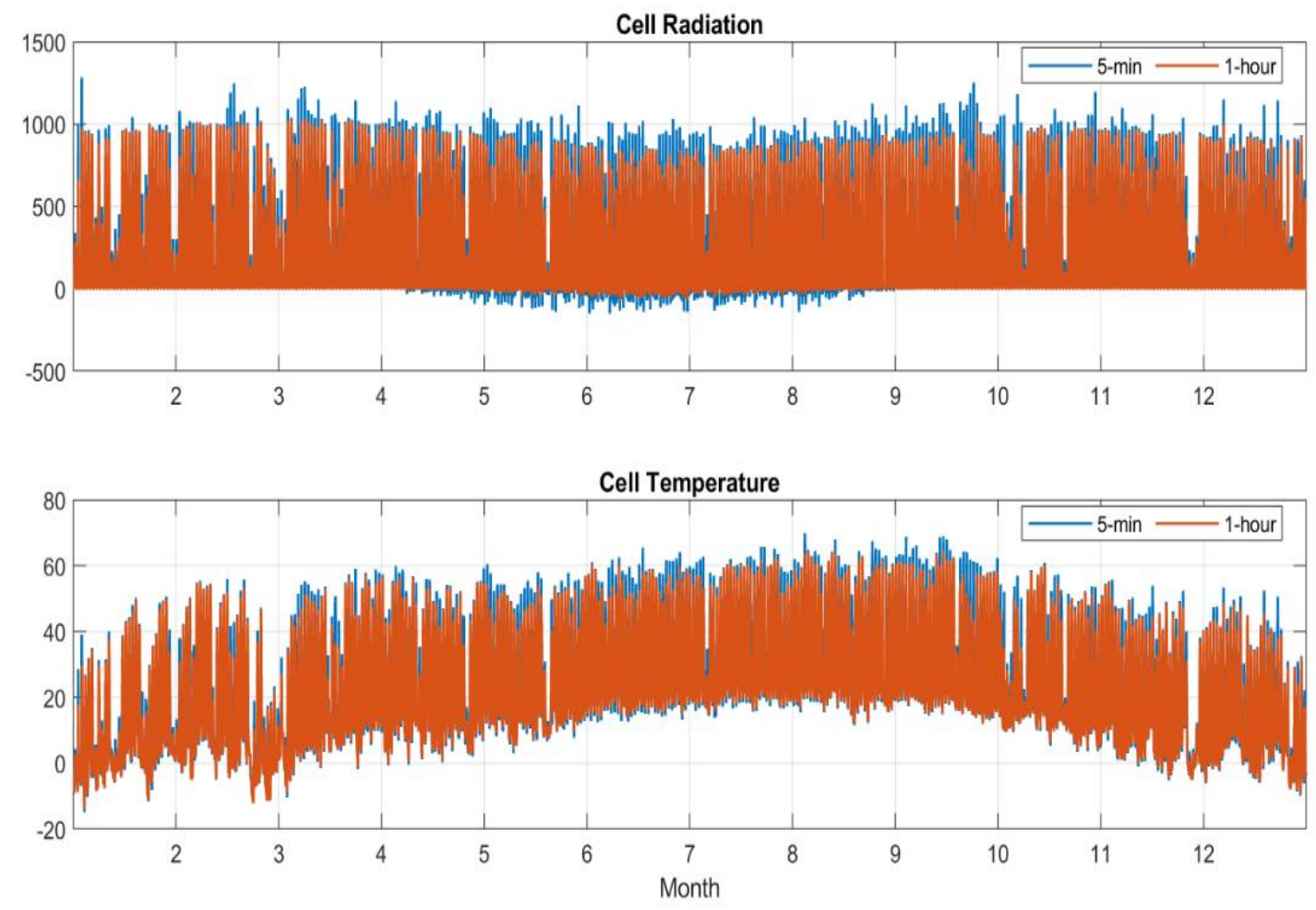

Fig. 3. Sun radiation and cell temperature

As shown in Fig. 3, the solar cell characteristic V-I is influenced by the two factors of radiation and temperature. This dependence on temperature and radiation is modeled with the following relations. As it is obvious, the cell temperature is higher during the summer months.

\subsection{Fuel Cell System (FC)}

Fuel cells transfer the energy of the fuel into electric energy by some chemical process. The fuel cell has great efficiency and reliability. The energy comes from fuel cells alongside with solar system that feeds the batteries of the electric cars [30]. The anode of the fuel cell is fed by hydrogen, and the cathode is fed by oxygen [31]. The fuel cell is a very suitable energy for EVs. The characteristics of the fuel cell are shown in Fig. 4. 


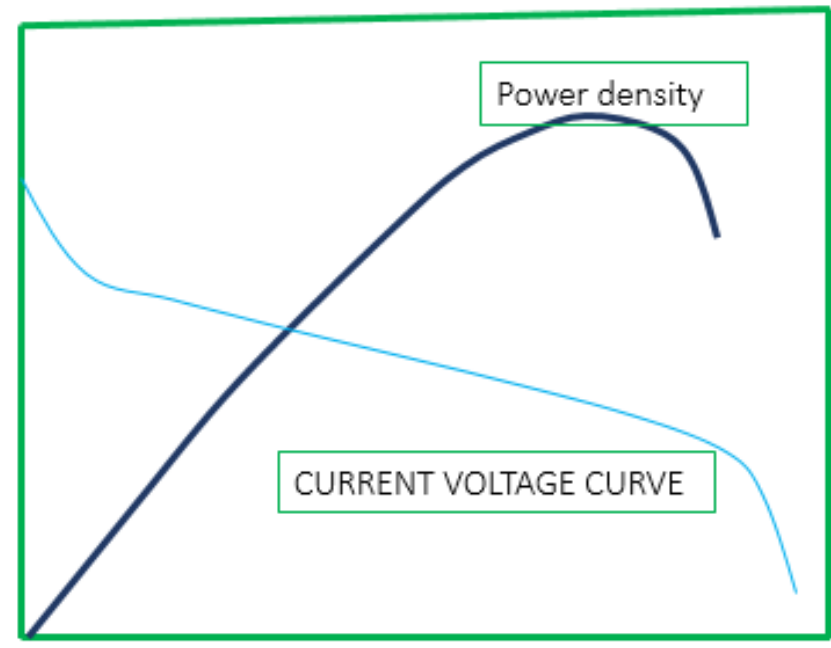

Fig. 4. FC Characteristics

\section{Presented DC-DC Topology}

The basic method is using a converter for each source of energy. In this paper, a multiport converter is utilized, which makes the system smaller and cheaper, and the result is smooth compared to the proposed method in [32]. A proposed topology depicts in Fig. 5. The presented topology has three switches which are MOSFETs, two resources which are fuel cell and solar cell, and some other components such as diode, inductors, capacitors, and resistors.

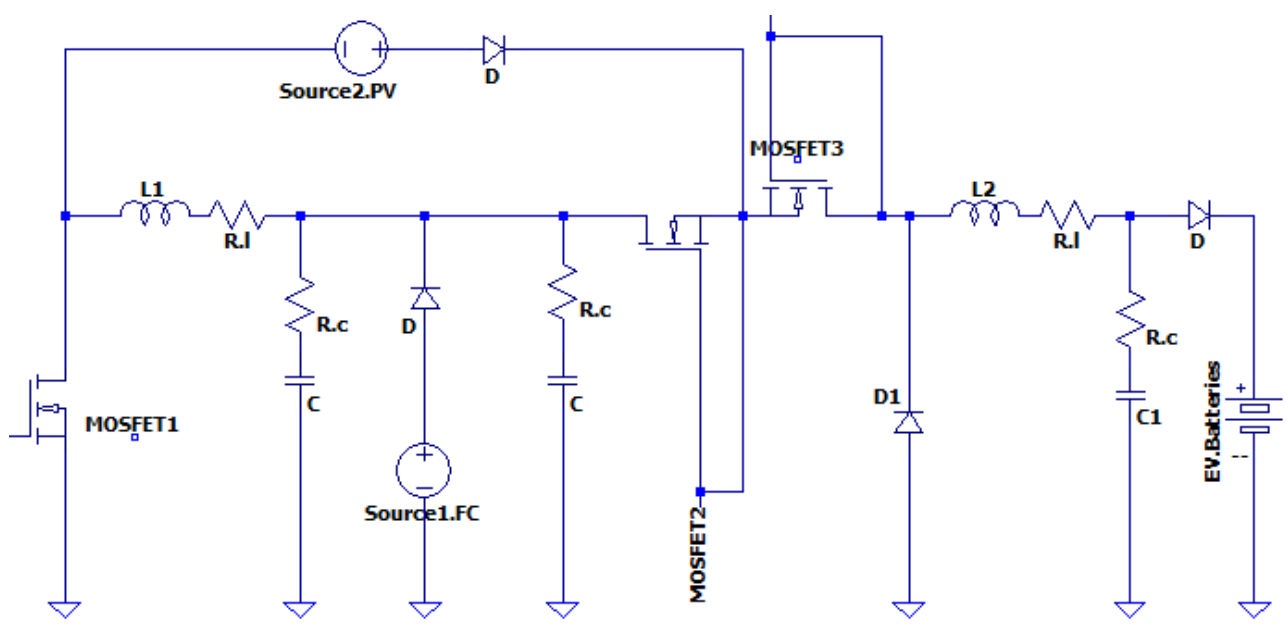

Fig. 5. Proposed DC-DC converter

The modes of operation in this topology are as follows. In the first mode of operation, MOSFET number 3 is disconnected; therefore, the energy stored in L2 and C1 feeds the battery of the EVs. Furthermore, both resources feed L1. In the second mode of operation, MOSFET number 3 is on; therefore, the energy stored in L1 and also the energy that comes from resources feed the battery of the EVs. Finally, in the third mode of operation, all three MOSFETs are on, and because of the nighttime, the PV source is not generating energy. Therefore, the energy stored in L1 and also the energy that comes from fuel cells feed the battery of the EVs.

\section{Results}

To simulate the whole system, including two resources and power converter, LTSPICE software is implemented. The presented topology works in continuous conduction mode (CCM). Table 1 shows the values of the components in the presented topology for the simulation and result purposes. 
Table 1. Parameter Value

\begin{tabular}{cccc}
\hline Parameter & Value & Parameter & Value \\
\hline L1 & $180 \mu \mathrm{H}$ & $\mathrm{C}$ & $120 \mu \mathrm{F}$ \\
L2 & $540 \mu \mathrm{H}$ & $C_{1}$ & $470 \mu \mathrm{F}$ \\
$R_{L}$ & $100 \mathrm{~m} \Omega$ & & \\
$R_{C}$ & $100 \mathrm{~m} \Omega$ & & \\
\hline
\end{tabular}

The generated voltage of the PV is 36 volts, and the generated voltage of the FC is 20 volts. The input and output voltage when using the PV source of energy is depicted in Fig. 6.

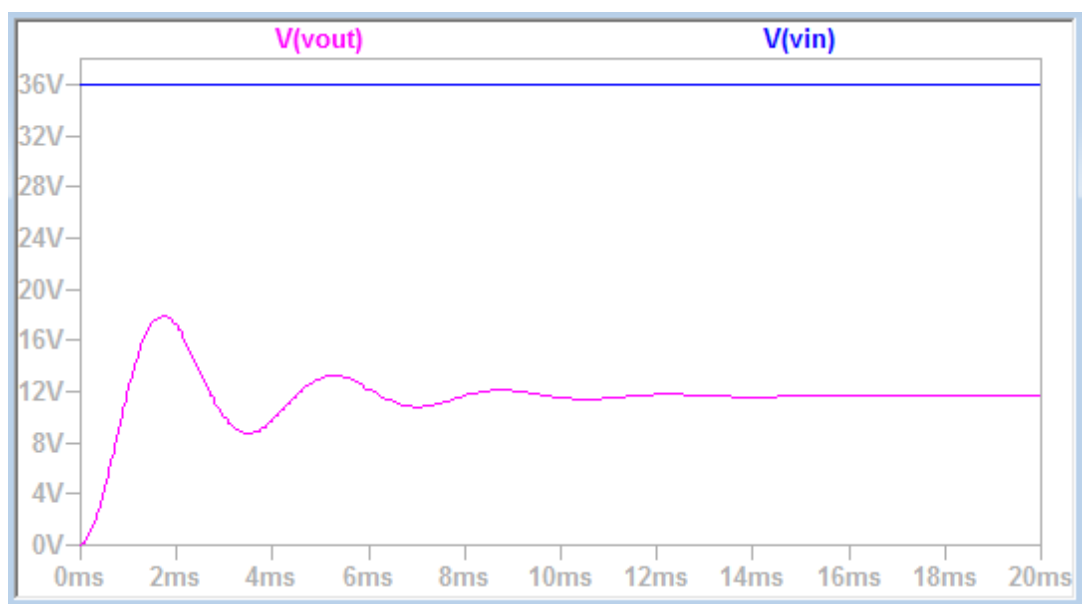

Fig. 6. The input and the output voltage of the proposed converter using PV source

According to Fig. 6, the input voltage of the system is 36 volts, and the output voltage is 12 volts, which feeds the batteries of the electric car. The input and output voltage when using the PV source of energy is depicted in Fig. 7.

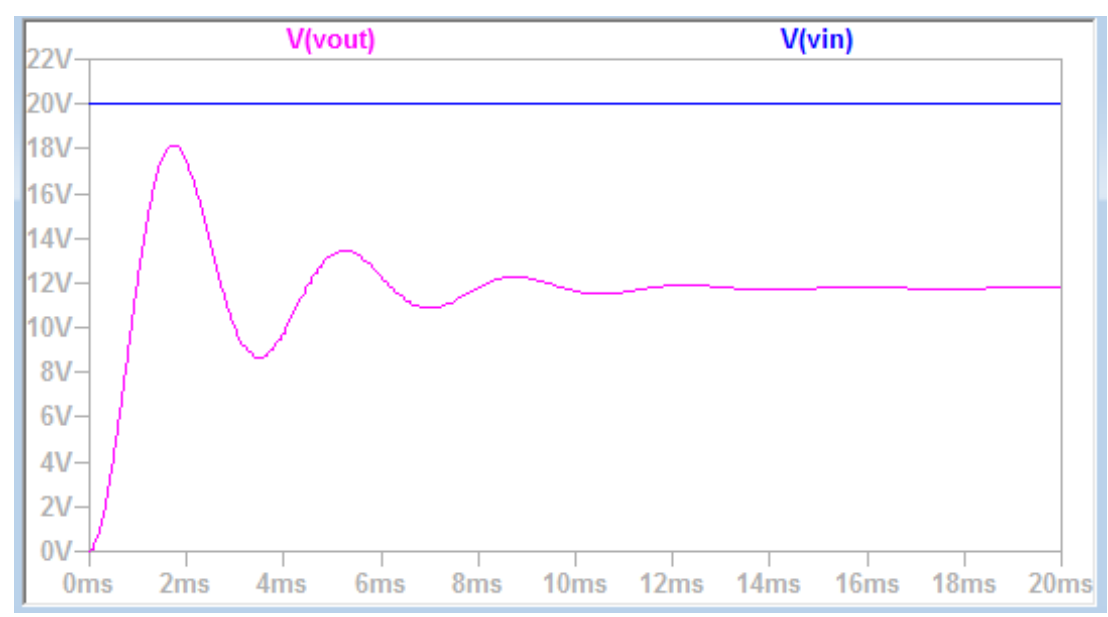

Fig. 7. The input and the output voltage of the proposed converter using FC source

According to Fig. 6 and Fig. 7, the input voltage of the system is 20 volts, and the output voltage is 12 volts, which feed the batteries of the electric car. In addition, as it is obvious based on the figures, there is no ripple in the 12-volts output. By having the lowest ripple, the power losses will be reduced, and the efficiency of the system will increase, respectively. Fig. 8 indicates the voltage across the MOSFET number 3 and the current through L1 when using PV as the resource. 


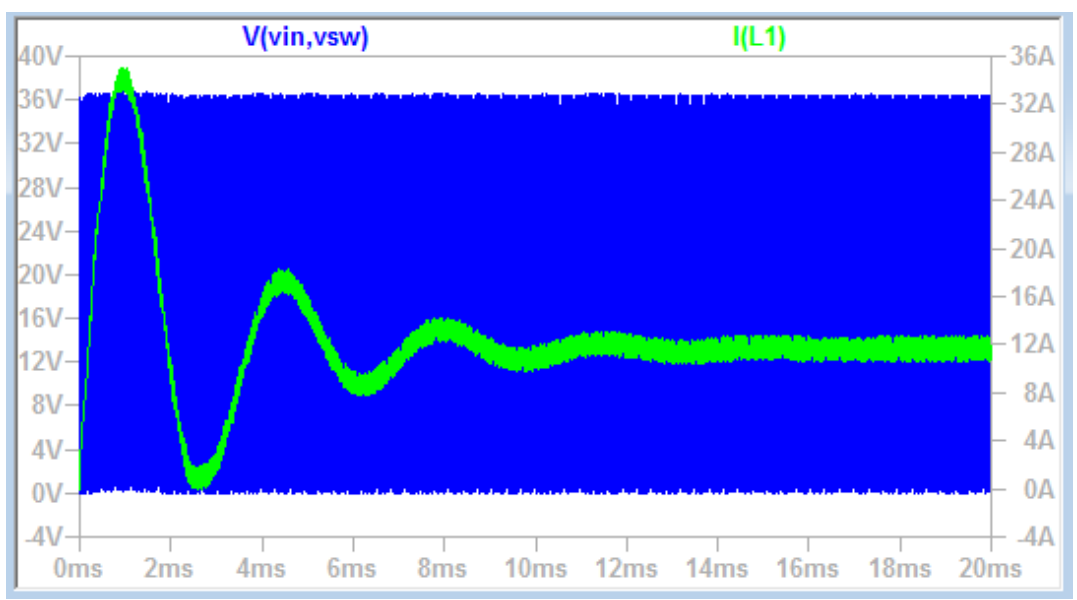

(a)

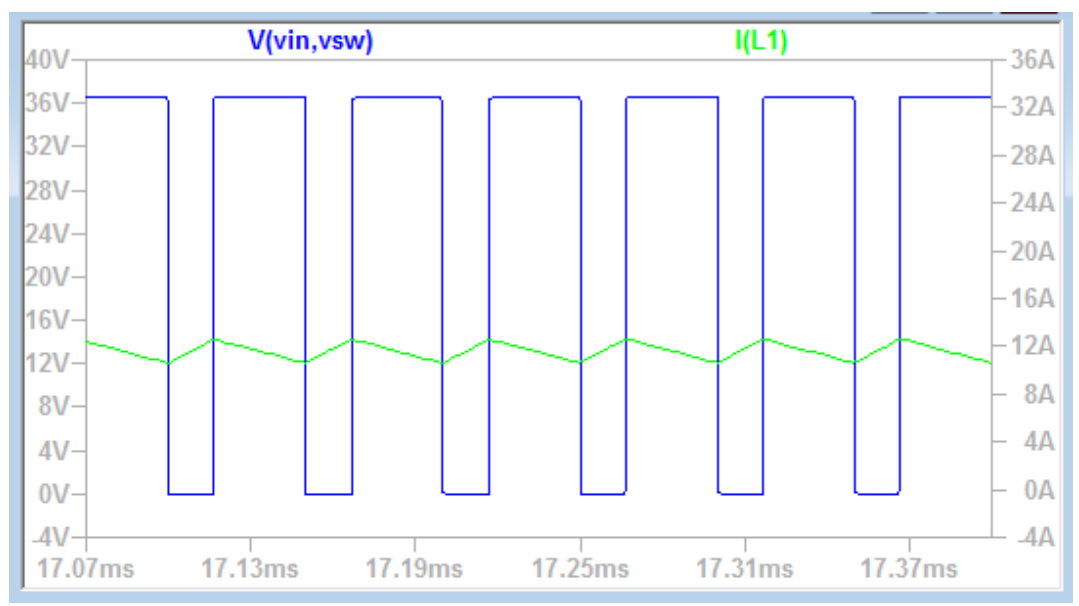

(b)

Fig. 8. The voltage across the MOSFET 3 and the CCM mode of the current through L1 using PV system

Fig. 9 shows the voltage across the MOSFET and the current through the inductor when using FC as the resource. According to Fig. 8 and Fig. 9, when MOSFET is off, the voltage across the MOSFET is equal to the input voltage, and the inductor is discharging. Also, when MOSFET is on, the voltage across the MOSFET is zero, and the inductor current is charging. Fig. 10 demonstrates the FFT of the inductor current.

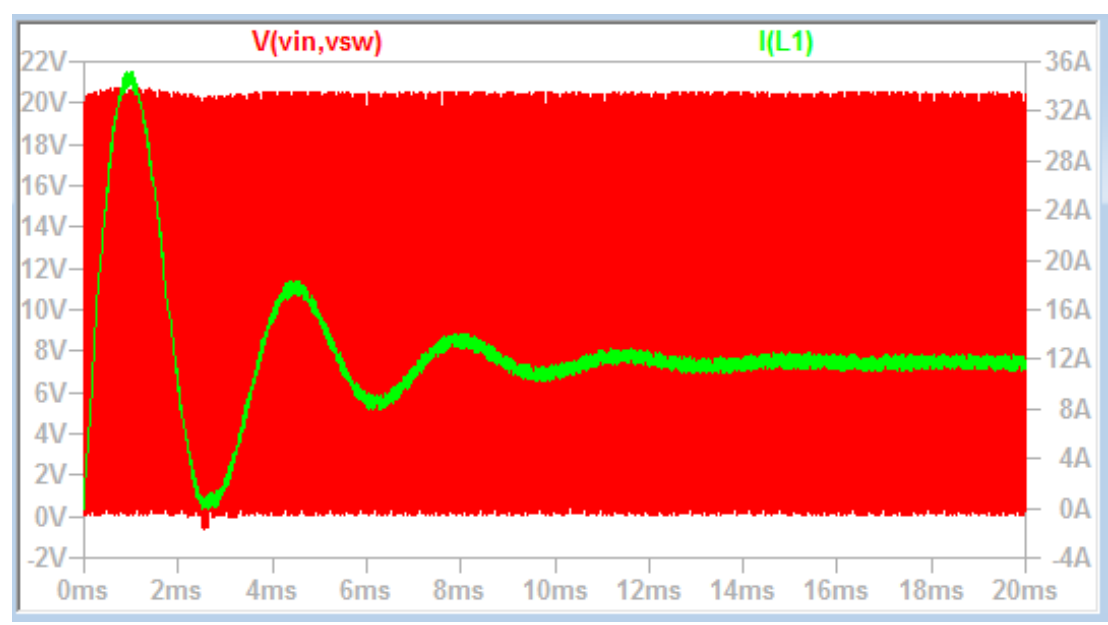

(a) 


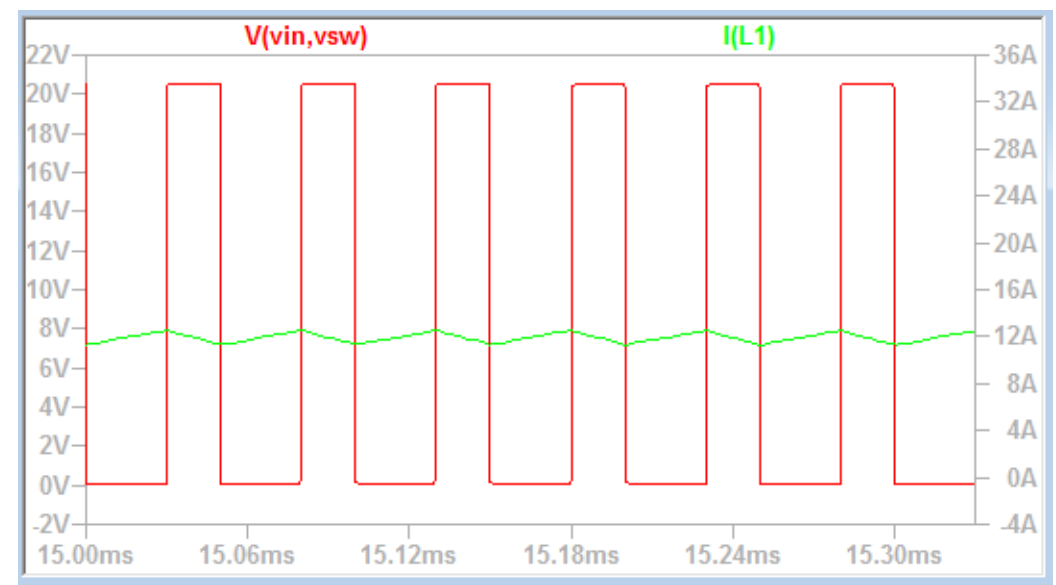

(b)

Fig. 9. Voltage across the MOSFET 3 and the CCM mode of the current through L1 using FC system

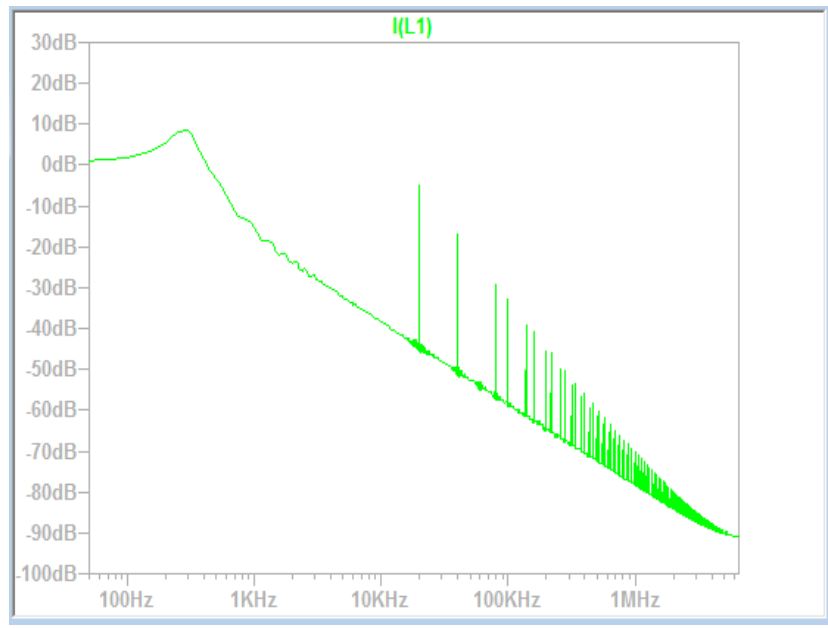

Fig. 10. FFT of L1 current

Based on Fig. 10, there are some harmonics in the inductor current. Fig. 11 indicates the FFT of the 12 volts output voltage. It is obvious from Fig. 11 that the amount of harmonics in the output voltage is much lower, and the output waveform is smooth.

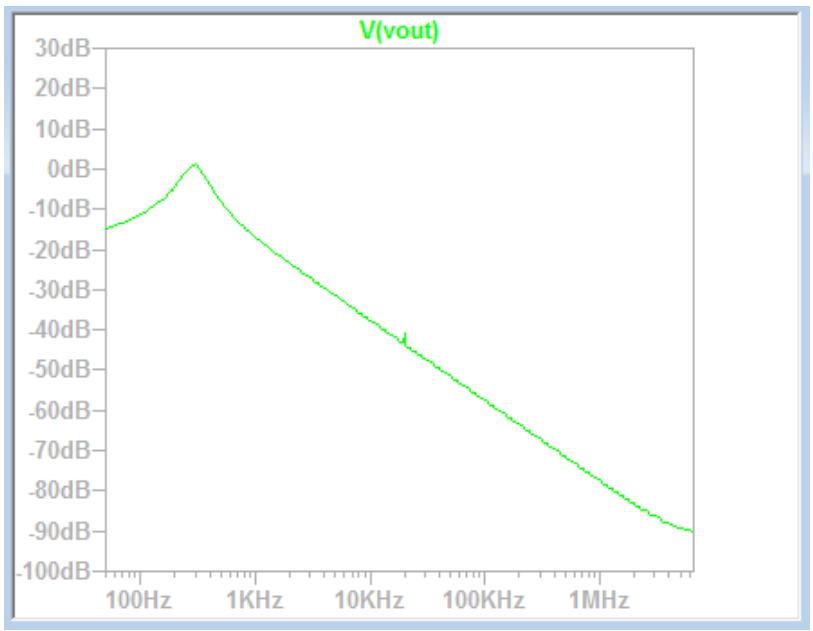

Fig. 11. FFT output voltage 


\section{Conclusion}

Renewable energy sources such as photovoltaic (PV) and fuel-cell (FC) technology are the sole options for supplying enough electricity. In order to use renewable energy, power converters are required. In this paper, for the proposed method, two standard DC-DC converters are required to transport the energy from renewable sources to the bank of batteries. This study presents a two-input, one-output architecture that includes PV, FC, and other components to feed the batteries. The simulation results show that the proposed method can feed the batteries with minimal power losses and ripples. In addition, the converter's output voltage has fewer harmonics, making the system more suited. Future research will focus on lowering the number of switches to reduce the electromagnetic interference of the system.

Author Contribution: All authors contributed equally to the main contributor to this paper. All authors read and approved the final paper.

Funding: This research received no external funding.

Conflicts of Interest: The authors declare no conflict of interest.

\section{References}

[1] V. Lozhkin, O. Lozhkina, and V. Dobromirov, "A study of air pollution by exhaust gases from cars in well courtyards of Saint Petersburg," Transportation research procedia, vol. 36, p. 453-458, 2018, https://doi.org/10.1016/j.trpro.2018.12.124.

[2] C. E. S. Thomas, "'How green are electric vehicles?"," International journal of hydrogen energy, vol. 37, no. 7, pp. 6053-6062, 2012, https://doi.org/10.1016/j.ijhydene.2011.12.118.

[3] T. R. Hawkins, O. M. Gausen, and A. H. Strømman, "Environmental impacts of hybrid and electric vehicles - a review," The International Journal of Life Cycle Assessment, vol. 17, no. 8, pp. 997-1014, 2012, https://doi.org/10.1007/s11367-012-0440-9.

[4] N. Martin and J. Rice, "Power outages, climate events, and renewable energy: Reviewing energy storage policy and regulatory options for Australia," Renewable and Sustainable Energy Reviews, vol. 137, p. 110617, 2021, https://doi.org/10.1016/j.rser.2020.110617.

[5] S. P. Holland, E. T. Mansur, N. Z. Muller, and A. J. Yates, "Distributional effects of air pollution from electric vehicle adoption," Journal of the Association of Environmental and Resource Economists, vol. 6, no. S1, p. S65-S94, 2019, https://doi.org/10.1086/701188.

[6] L. S. Martins, L. F. Guimarães, A. B. B. Junior, J. A. S. Tenório, and D. C. R. Espinosa, "Electric car battery: An overview on global demand, recycling and future approaches towards sustainability," Journal of Environmental Management, vol. 295, p. 113091, 2021, https://doi.org/10.1016/j.jenvman.2021.113091.

[7] B. Moaveni, F. R. Fathabadi, and A. Molavi, "Fuzzy control system design for wheel slip prevention and tracking of desired speed profile in electric trains," Asian Journal of Control, vol. 24, no. 1, pp. 388-400, 2022, https://doi.org/10.1002/asjc. 2472.

[8] S. S. Deshmukh and J. M. Pearce, "Electric vehicle charging potential from retail parking lot solar photovoltaic awnings," Renewable Energy, vol. 169, pp. 608-617, 2021. https://doi.org/10.1016/j.renene.2021.01.068

[9] M. A. Hannan, F. Azidin, and A. Mohamed, "Hybrid electric vehicles and their challenges: A review," Renewable and Sustainable Energy Reviews, vol. 29, pp. 135-150, 2014, https://doi.org/10.1016/j.rser.2013.08.097.

[10] T. Wilberforce, Z. El-Hassan, F. N. Khatib, A. Al Makky, A. Baroutaji, J. G. Carton, and A. G. Olabi, "Developments of electric cars and fuel cell hydrogen electric cars," International Journal of Hydrogen Energy, vol. 42, no. 40, pp. 25695-25734, 2017, https://doi.org/10.1016/j.ijhydene.2017.07.054

[11] P. Eskandari and S. B. Shokouhi, "Automated Atlas-Based Segmentation of Breast Region in 3-D Magnetic Resonance Imaging (MRI) Using FCM Method," Mapta Journal of Electrical and Computer

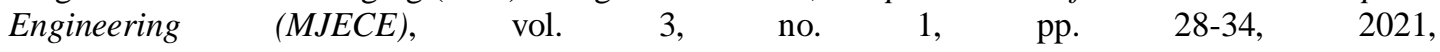
https://maptapublishing.com/index.php/mjece/article/view/175

[12] P. Eskandari and S. B. Shokouhi, "DT-CWT: A New Feature for Tumor Classification in Breast DCEMRI," Mapta Journal of Electrical and Computer Engineering (MJECE), vol. 3, no. 1, p. 35-39, 2021, https://maptapublishing.com/index.php/mjece/article/view/180. 
[13] M. Dhananjaya and S. Pattnaik, "Review on Multi-Port DC-DC Converters," IETE Technical Review, pp. 1-14, 2021, https://doi.org/10.1080/02564602.2021.1882343

[14] Z. Li, A. Khajepour, and J. Song, "A comprehensive review of the key technologies for pure electric vehicles," Energy, vol. 182, p. 824-839, 2019, https://doi.org/10.1016/j.energy.2019.06.077

[15] S.Wang, Z. Zheng, C. Li, K. Wang, and Y. Li, "Time domain analysis of reactive components and optimal modulation for isolated dual active bridge DC/DC converters," IEEE Transactions on Power Electronics, vol. 34, no. 8, p. 7143-7146, 2019, https://doi.org/10.1109/TPEL.2019.2897007

[16] S. Chakraborty, H.-N. Vu, M. M. Hasan, D.-D. Tran, M. E. Baghdadi, and O. Hegazy, "DC-DC converter topologies for electric vehicles, plug-in hybrid electric vehicles and fast charging stations: State of the art and future trends," Energies, vol. 12, no. 8, p. 1569, 2019, https://doi.org/10.3390/en12081569

[17] S. Dinkhah, C. A. Negri, M. He, and S. B. Bayne, "V2G for reliable microgrid operations: Voltage/frequency regulation with virtual inertia emulation," 2019 IEEE Transportation Electrification Conference and Expo (ITEC), 2019, pp. 1-6, https://doi.org/10.1109/ITEC.2019.8790615.

[18] S. Dinkhah and M. He, "Self-adjusting Inertia Emulation Control in V2G Application," 2020 IEEE Green Technologies Conference (GreenTech), 2020, pp. 127-132, https://doi.org/10.1109/GreenTech46478.2020.9289787.

[19] Villegas-Mier, C.G., et al., "Artificial neural networks in MPPT algorithms for optimization of photovoltaic power systems: A review," Micromachines, vol. 12, no. 10, p. 1260, 2021, https://doi.org/10.3390/mi12101260.

[20] R. S. Taremi, P. K. Shahri, and A. Y. Kalareh, "Design a tracking control law for the nonlinear continuous time fuzzy polynomial systems," Journal of Soft Computing and Decision Support Systems, vol. 6, no. 6, p. 21-27, 2019, http://www.jscdss.com/index.php/files/article/view/216

[21] A. Yousefiankalareh, A. Najari, and M. Hosseynzadeh, "Tree-based Routing Protocol in Wireless Sensor Networks using Optimization Algorithm Batch Particles with a Mobile Sink," 2020 IEEE 17th International Conference on Smart Communities: Improving Quality of Life Using ICT, IoT and AI (HONET), 2020, pp. 1-5, https://doi.org/10.1109/HONET50430.2020.9322844

[22] F. Shahabi, A. Rouhi, and R. Rastegari, "The Performance of Deep and Conventional Machine Learning Techniques for Skin Lesion Classification," 2021 IEEE 18th International Conference on Smart Communities: Improving Quality of Life Using ICT, IoT and AI (HONET), 2021, pp. 50-55, https://doi.org/10.1109/HONET53078.2021.9615400

[23] A. Balal and M. Giesselmann, "Demand Side Management and Economic Analysis Using Battery Storage System (BSS) and Solar Energy," 2021 IEEE 4th International Conference on Power and Energy Applications (ICPEA), 2021, pp. 141-146, https://doi.org/10.1109/ICPEA52760.2021.9639359.

[24] B. Moaveni, F. R. Fathabadi, and A. Molavi, "Supervisory predictive control for wheel slip prevention and tracking of desired speed profile in electric trains," ISA transactions, vol. 101, pp. 102-115, 2020, https://doi.org/10.1016/j.isatra.2020.01.011

[25] A. Sabadus and M. Paulescu, "On the Nature of the One-Diode Solar Cell Model Parameters," Energies, vol. 14, no. 13, p. 3974, 2021, https://doi.org/10.3390/en14133974

[26] R. B. Bollipo, S. Mikkili, and P. K. Bonthagorla, "Critical review on PV MPPT techniques: classical, intelligent and optimisation," IET Renewable Power Generation, vol. 14, no. 9, pp. 1433-1452, 2020, https://doi.org/10.1049/iet-rpg.2019.1163.

[27] A. Balal and F. Shahabi, "Ltspice Analysis of Double-Inductor Quadratic Boost Converter in Comparison with Quadratic Boost and Double Cascaded Boost Converter," 2021 12th International Conference on Computing Communication and Networking Technologies (ICCCNT), 2021, pp. 1-6, https://doi.org/10.1109/ICCCNT51525.2021.9579931.

[28] E. Kabir, P. Kumar, S. Kumar, A. A. Adelodun, and K. -H. Kim, "Solar energy: Potential and future prospects," Renewable and Sustainable Energy Reviews, vol. 82, pp. 894-900, 2018, https://doi.org/10.1016/j.rser.2017.09.094

[29] M. K. H. Rabaia, M. A. Abdelkareem, E. T. Sayed, K. Elsaid, K.-J. Chae, T. Wilberforce, and A. G. Olabi, "Environmental impacts of solar energy systems: A review," Science of The Total Environment, vol. 754, p. 141989, 2021, https://doi.org/10.1016/j.scitotenv.2020.141989.

[30] J. Crosby, H. R. K. M. Emani, X. Zhang, D. Maddipatla, S. Ahmadi, Q. Wu, B. Bazuin, M. Stoops, and M. Atashbar, "Development of a Zn/MnO 2 Based Flexible Battery," 2021 IEEE International Flexible Electronics Technology Conference (IFETC), 2021, pp. 0035-0037, https://doi.org/10.1109/IFETC49530.2021.9580507.

[31] S. Ahmadi, G. Wang, D. Maddipatla, Q. Wu, W. Lu, and M. Z. Atashbar, "Investigating the Impact of Thickness, Calendering and Channel Structures of Printed Electrodes on the Energy Density of LIBs- 
3D Simulation and Validation," 2021 IEEE International Flexible Electronics Technology Conference (IFETC), 2021, pp. 1-3, https://doi.org/10.1109/IFETC49530.2021.9580515.

[32] A. Balal and M. Herrera, "Design a Power Converter to Charge a Hybrid Electric Vehicle," 2021 IEEE 18th International Conference on Smart Communities: Improving Quality of Life Using ICT, IoT and AI (HONET), 2021, pp. 56-60, https://doi.org/10.1109/HONET53078.2021.9615492. 